Artigos 


\section{Mitologias institucionais brasileiras: do Leviatã paralítico ao Estado de natureza}

\section{WANDERLEY GUILHERME DOS SANTOS}

A mitologia política do Brasil é tão rica quanto à indígena, porém bem menos inocente. Nenhum mal decorre dos mitos e ritos dos Araweté, por exemplo, mas as lendas que congestionam o imaginário político nacional costumam condicionar decisóes cujos efeitos perversos ameaçam a estabilidade das instituiçóes e o cotidiano dos cidadăos. O que há em comum entre as mitologias indígena e política é a sua total impermeabilidade a evidências contrárias a seus respectivos dogmas. Mitologias sáo defensivamente espessas, inconsúteis e somente a seta do tempo ou cataclismos desesperadores conseguem nelas produzir abalos significativos. Por vezes, alguns desses cataclismos resultam da voluntária cegueira dos mitômanos perante fenômenos $\mathrm{e}$ fatos escandalosa e ululantemente óbvios. Nada, contudo, é mais invisível do que o óbvio - e com esta melancólica expectativa, tentarei torná-lo conspícuo mediante pobres miçangas de retórica.

O mito de que o Estado brasileiro é absurdamente grande, paquidérmico, tem sido responsável por políticas administrativas com relação à burocracia pública, cujo resultado demonstra-se oposto ao pretendido. Ao contrário de agilizar a capacidade operacional do Estado, aumentar sua eficiência e credibilidade, produziu-se o desmantelamento das poucas estruturas ainda eficazes, comprometeram-se a capacidade fiscalizatória, ordenadora e extrativa do Estado de maneira que, hoje, os pobres e desvalidos dele nada esperam, enquanto ricos e poderosos dele nada temem. Mais de quarenta por cento daqueles que em 1992 deveriam prestar contas ao fisco náo o fizeram - comportamento dos que não temem, porque têm - enquanto mais de sessenta por cento vitimados por agressão, roubo ou furto preferiram não arriscar, pelo desperdício, a buscar justiça ou polícia em vão - conformismo dos que nada esperam, porque pouco ou nada têm. Uma coisa de cada vez, porém.

Desde mais ou menos 1984, insuspeitos relatórios de agências 
internacionais vêm produzindo dados comprovando abundantemente ser o Brasil um Estado mais para sovina do que para perdulário. Isso, absoluta e comparativamente falando. $O$ total de gastos do setor público brasileiro correspondeu, em 1981, a 19,5\% do Produto Nacional Bruto. No mesmo ano, a média dos gastos de países com renda per capita de dois a quatro mil dólares (entre os quais se inclui o Brasil), girou em torno de $27,6 \%$ do PNB. A diferença entre a proporção da participação estatal brasileira no PNB, e também a dos demais países na mesma classe de renda, não é explicada pela diferença entre as rendas per capita intraclasse: a renda média per capita daqueles países era de US\$ 2.449 , enquanto a do Brasil, US\$ 2.240.

Ninguém diria que Estados Unidos, Itália, Espanha e Suécia tivessem pervertido o caráter democrático de seus regimes por conta de exagerada participaçáo estatal no PNB. No entanto, as porcentagens correspondentes são as seguintes: EUA, 23,4\%; Itália, 47,3\%; Espanha, 27,3\%; e Suécia, 43,7\%. Entre os países desenvolvidos, apenas o Japão assemelha-se ao Brasil, com a taxa de $19 \%$ de participaçáo do setor estatal no PNB. Se é verdade que a Suécia apresenta parcos $18,3 \%$ desse tipo de participação, também é verdade que a holandesa alcança $55,5 \%$.

O Estado brasileiro é um gigante pela própria natureza face ao Estado ugandense, com seus $3,2 \%$ de participaçáo no PNB, ou ao de Gana $(10,1 \%)$, ao do Nepal $(13,4 \%)$ e ao do Alto Volta $(14,6 \%)$. Até mesmo perante o Estado indiano (14\%), o brasileiro pode parecer enorme. Já nem tanto diante dos Estados salvadorenho e tailandês (ambos com $18,5 \%$ de participaçáo estatal), ou mesmo equatoriano $(17,1 \%)$. Estes casos referem-se a países com renda média per capita pelo menos três vezes inferior à brasileira. Aos assustados com o gigantismo do Estado brasileiro, e céticos, recomendo o Relatório sobre o desenvolvimento mundial - 1984, do Banco Mundial, publicado pela Fundação Getúlio Vargas.

Diz-se que a elefantíase estatal manifesta-se no elevado contingente de empregados públicos de todo tipo: estatutários, celetistas, das administraçôes direta $\mathrm{e}$ indireta. Eis, contudo, alguns números. $\mathrm{O}$ total de empregados públicos no Brasil, tomado como porcentagem da populaçăo economicamente ativa não agrícola, correspondia a $9,6 \%$ desta última em 1984. Na Argentina e no Panamá, países na mesma faixa de renda per capita, essas taxas eram $22,7 \%$ e $28,6 \%$ respectivamente.

Sabe-se que a magnitude e composição do funcionalismo depende do padráo de gastos públicos. Ou seja, um país laissez-fairiano clássico possuirá pequeno número de funcionários concentrados em atividades 
de defesa e administração, enquanto países de tipo mais moderno tenderão a empregar maior número de pessoas distribuídas entre atividades sociais, econômicas de administração e defesa, nessa ordem, ou alternando-se apenas as de adminiştraçáo e econômicas. $O$ padrão brasileiro liga-o à família de países cujos gastos ordenam-se, decrescentemente, em sociais, de administração, econômicos e defesa. A esta família pertencem, entre outros, Canadá, Holanda, Itália, Suécia e Nova Zelândia. Para que não se insinue andar o Brasil somente na companhia dos ricos, também fazem parte desse grupo os primos pobres El Salvador e Senegal.

Desta seleta família é o Estado brasileiro o que menos emprega força de trabalho náo agrícola. O segundo membro mais parcimonioso, o Canadá, emprega $16,4 \%$, a Holanda $19 \%$, a Itália $20 \%$, a Suécia $34 \%$ e a Nova Zelândia $36,5 \%$. Náo se trata de empreguismo perdulário, pois os primos pobres Senegal e El Salvador ocupam, respectivamente, $46 \%$ e 49\% da PEA não agrícola. Aos céticos, recomendo o relatório do FMI, Emprego e salários governamentais: algumas comparafóes internacionais, edição revista, março 1984.

O pseudo gigantismo estatal é uma névoa que distorce a questão essencial: o Estado brasileiro é ridiculamente pequeno e disforme, isto é, está onde náo deveria, ao preço de não se encontrar onde a responsabilidade social de um Estado moderno demandaria. Por exemplo, enquanto o Chile, com renda per capita inferior à do Brasil, destina $19,6 \%$ do PNB a programas sociais, e o Uruguai $15,4 \%$, o Brasil aloca apenas $9 \%$ de seu PNB a projetos de natureza social, como se esses dois países padecessem de carências e misérias superiores às nossas e não ocorresse o contrário.

O outro lado da moeda revela que o Uruguai gasta $2,6 \%$ de seu PNB com administraçáo, o Chile 4,1\% e o Brasil, o dobro do Uruguai $(5,2 \%)$. Mas o problema do emprego público não se limita ao fato de o Estado estar desassistido de recursos humanos para desempenho eficaz em áreas de sua responsabilidade, enquanto há excesso de pessoal em funçóes subalternas ou supérfluas. A má distribuição do funcionalismo torna-se mais patente quando se penetra na intimidade das agências públicas.

Tome-se a relação entre operadores ou pessoal ocupado em atividades-fim e administradores; as Ceasas, por exemplo, na área do abastecimento. Enquanto a do Rio de Janeiro emprega nove operadores por cada burocrata e a do Espírito Santo sete por um, a Ceasa do Pará emprega três burocratas por cada dois operadores e a do Maranhão um por cada operador final. $\mathrm{Na}$ área das telecomunicaçóes encontramos a 
Tele-Paraná ocupando um administrador por cada seis operadores, ao passo que a Tele-Pernambuco emprega quatro burocratas por operador. $\mathrm{Na}$ Siderurgia verifica-se a Usiminas empregando oito operadores por administrador, enquanto a Usina Siderúrgica da Bahia ocupa praticamente um burocrata por cada operador. E assim por diante, segundo o Cadastro das Empresas Estatais (v. publicaçóes da Sest).

Anão morfologicamente disforme, o Estado brasileiro constitui um caso de múltipla personalidade e comportamento variado. As várias faces do anão, quero dizer, do Adão estatal têm a peculiaridade de aparecer simultaneamente, sem exigir psicanálise profunda. $O$ experimento com práticas poliárquicas expressa-se, por exemplo, nos programas de açáo comunitária, os quais dependem do envolvimento voluntário das associaçóes locais, da micro-solidariedade dos pequenos grupos em torno de problemas específicos. Diversos experimentos semelhantes estáo em curso no país, o que é desejável, envolvendo toda a gama de grupos voluntários.

Grupos de trabalho e comissões sáo instaurados com a participação de representantes dos diferentes interesses em disputa. Têm eles a co-responsabilidade de formular políticas que exprimam um mínimo divisor comum, isto é, aquele curso de ação que maximize os ganhos de cada grupo no limite do consentimento dos demais. A expectativa é de que funcionem como as câmaras políticas escandinavas, a saber, como lugar institucionalizado para a expressáo de divergências na etapa de formulaçáo política, comprometendo os participantes com a decisão negociada. Ao contrário de tentar produzir um plano isento da contaminação de interesses, reconhece-se desde logo a existência de interesses conflitantes, e o problema político consiste em obter uma decisão que seja a expressáo do conflito negociado, garantindo-se a sua implementaçáo.

Incontinenti, reencontramos o velho corporativismo subdesenvolvido, encarnado em outro tipo de conselho, no qual deve estar presente a santíssima trindade corporativa: representantes do Estado, dos empregadores e dos empregados. Apenas aparentemente este conselho é confundido com o tipo descrito anteriormente. Distingue-os o fato de que as câmaras políticas reconhecem o pluralismo na representaçáo de interesses similares, privados e governamentais, a nenhum sendo delegado o monopólio da representação. Justo o contrário do que ocorre nos conciliábulos tripartites corporativos, nos quais se uniformiza e concentra, por decreto, o que é de si heterogêneo e disperso. Por isso é que as câmaras de estilo escandinavo são interministeriais e multi-representacionais e nas câmaras de modelo corporativo subdesenvolvido, 
entulho remanescente da ditadura varguista, reina o monopólio da representação, o que é péssimo.

Enquanto assim for, o Estado brasileiro não passará de um anão disforme, despreparado para executar com eficácia qualquer programa de governo, por mais generoso que sejam seus príncipes, generais ou presidentes.

O Estado que nos cerca, portanto, náo configura caso especial de um Estado-providência, ou provedor, a dispensar favores, magnânimo, sem discriminaçáo de classes, segmentos ou regióes. Justo o contrário, ele é pequeno precisamente porque, em parte, ele opera segundo uma lógica privada e oligarquizante para benefício de poucos. Por isso, no Brasil, a provisão de bens realmente públicos, aqueles bens classicamente liberais - educação, saúde, lei e ordem - é deficitária e deficiente. Daí, também o descrédito associado à capacidade operacional do Estado. Conforme inquérito recente, $60 \%$ das pessoas vítimas de roubo e furto - entre outubro de 1987 e setembro de 1988 - não procuraram as autoridades policiais por considerarem esse procedimento perda de tempo; aproximadamente a mesma porcentagem é observada em qualquer das regióes do país. Em contraponto, e no mesmo período, $\mathbf{5 4 \%}$ das vítimas de agressão física também não recorreram à polícia pelas mesmas razóes de desesperança. Outra vez, as estatísticas são semelhantes em todas as regiōes brasileiras.

É a percepção do Estado como anão, antes de como gigante, e anão socialmente preconceituoso, que está na origem do escandaloso fenômeno da sonegação do conflito. O mesmo inquérito de 1988 encontrou que, de uma populaçáo de 18 anos e mais, equivalente a 82.514.819 pessoas, somente dez por cento reconheceram algum envolvimento em conflito, entre nove tipos de opçáo, durante os cinco anos antecedentes ao inquérito. Este resultado esdrúxulo é exponenciado pela informação de que, quando desagregado, fica-se sabendo que conflitos sobre posse de terra, isto é, os reconbecidos, náo envolveram durante cinco anos, mais de $0,6 \%$ da população rural.

Se à população parece melhor manter discrição sobre os conflitos nos quais se enreda do que torná-los públicos, aqueles que optam por admiti-los não dão continuidade pública ao processo de administrá-los e resolvê-los. Do total de pessoas que reconheceram participaçáo em conflito, $67 \%$ náo buscaram a justiça para a sua solução. De novo, esta estatística vale para o Brasil e, com pequenas variaçóes, para todas as regiōes do país. Ver tabela 1 : 
Populaçáo de 18 anos e mais (1985-88) envolvida em conflito, por tipo de reação - Brasil e Regiōes ( $\mathbf{N}=\mathbf{8 . 6 4 1 . 7 6 1 )}$

\begin{tabular}{lrrrrrr}
\hline Porcentagem da populaçắ & Brasil & N & NE & SE & \multicolumn{1}{c}{$S$} & CO \\
\hline $\begin{array}{l}\text { Participantes em conflito que } \\
\text { não buscaram justiça }\end{array}$ & 67,0 & 60,0 & 65,0 & 64,0 & 68,0 & 67,0 \\
$\begin{array}{l}\text { Participantes que resolveram } \\
\text { por conta própria }\end{array}$ & 43,0 & 41,0 & 34,2 & 42,0 & 50,0 & 55,0 \\
$\begin{array}{l}\text { Participantes que temeram represálias } \\
\text { Participantes descrentes da justiç; }\end{array}$ & 1,5 & 1,2 & 1,8 & 1,8 & 0,8 & 0,5 \\
$\begin{array}{l}\text { năo quiseram envolvimento: } \\
\text { custava menos ser indiferente }\end{array}$ & & & & & & \\
$\begin{array}{l}\text { ao conflito } \\
\text { Recorreram a outras pessoas ou entidades }\end{array}$ & 6,0 & 7,0 & 6,3 & 6,0 & 6,2 & 5,0 \\
\hline
\end{tabular}

Fonte: FIBGE, Participafro politica e social, v.1, Rio de Janeiro, 1990, várias tabelas.

O mito do gigantismo do Estado, pelo lado da oferta de participaçáo estatal tem, portanto, sua contrapartida na escassez de demanda. $\mathrm{Na}$ realidade trata-se de recusa da cidadania em socorrer-se de instituiçōes pilares do Estado, justiça e órgãos de segurança, para a solução de seus problemas cotidianos. Hipótese trivial e recorrente na literatura buscaria explicar o fenômeno da sonegaçáo do conflito pela existência de um equivalente funcional às desacreditadas instituiçóes do Estado vasta rede de interaçóes clientelísticas entre a população, sobretudo de baixa renda, e a classe política. A inoperância estatal seria, assim, condição indispensável para que pudesse prosperar a prestação fisiológica de serviços, com pagamentos em votos. Indício empírico da plausibilidade da hipótese encontrar-se-ia em intenso comércio de contratos e interaçóes entre a classe política e suas bases eleitorais, particularmente as mais carentes. Contudo, o cerco fisiológico ao Congresso constitui mais uma das mitologias institucionais brasileiras.

Das mesmas 82.514 .891 pessoas com 18 anos ou mais, somente 5.45 1.541 haviam tido algum tipo de contato com políticos ou governantes até entáo, 1988. Tal número corresponde a reduzidíssimos $6,6 \%$ do número de contatos possíveis, atribuindo-se pelo menos um contato político a cada adulto. Ou seja, se a cidadania encontra-se desassistida do Estado e nem nele confia, náo é porque se valha de uma relação direta, personalizada e coronelística com seus representantes políticos. Cobrar soluçōes àqueles eleitos para produzi-las não parece fazer parte do imaginário ou do estoque de opçóes de comportamento da população. Em 
forte contradição com o mito do cerco fisiológico encontra-se, sobretudo, a evidência de que justamente o conjunto mais carente da população - aqueles que não têm rendimento algum, ou recebem mensalmente um piso nacional de salário - é o conjunto de necessitados que menos contatos estabelece com políticos - proposição que vale aproximadamente para todas as regióes do país, conforme a seguinte tabela:

\section{Tabela 2}

Porcentagem das pessoas de 18 anos ou mais, que realizaram algum tipo de contrato com políticos ou governantes, por região, segundo as classes de rendimento mensal

(Piso Nacional de Salário) - 1988

\begin{tabular}{lcrrrr}
\hline Classes de rendimento & $\mathrm{N}$ & $\mathrm{NE}$ & $\mathrm{SE}$ & \multicolumn{1}{c}{$S$} & $\mathrm{CO}$ \\
\hline Até $1 / 2$ & 4,2 & $\mathbf{6 , 4}$ & 4,4 & $\mathbf{8 , 8}$ & $\mathbf{5 , 6}$ \\
$>1 / 2$ até 1 & 5,9 & 7,6 & 5,1 & $\mathbf{8 , 3}$ & $\mathbf{6 , 0}$ \\
$>1$ a 2 & 4,5 & 7,3 & 4,6 & $\mathbf{8 , 8}$ & $\mathbf{8 , 6}$ \\
$>2$ a 3 & $\mathbf{6 , 3}$ & 7,8 & $\mathbf{5 , 0}$ & 13,0 & $\mathbf{8 , 7}$ \\
$>$ 3 a 5 & 5,4 & $\mathbf{9 , 2}$ & $\mathbf{6 , 5}$ & 14,0 & 11,6 \\
$>5$ a 10 & $\mathbf{8 , 2}$ & 13,0 & $\mathbf{8 , 5}$ & 17,0 & 16,2 \\
+ 10 & 8,4 & 17,6 & 11,0 & 20,0 & $\mathbf{2 3 , 0}$ \\
Sem rendimento & 3,1 & 4,7 & $\mathbf{3 , 3}$ & 4,2 & 4,1 \\
\hline
\end{tabular}

Fonte: FIBGE. Participação polttico-social. v.2, Educaçăo, meios de transporte, cadastro e associativismo. Rio de Janeiro, 1990, várias tabelas.

Diante de tal quadro de timidez reivindicatória, não deve espantar ou escandalizar se aqueles que buscam contato, e possuem renda mais alta, estiverem mais propensos a dar sugestōes aos políticos do que a demandar prestação personalizada de serviços - considerado como excelente indicador de espírito cívico - enquanto os intimidados, pobres e miseráveis, constituam a maior parcela dos que encaminham pedidos, a tanto resumindo-se as sugestôes que têm a fazer. Conforme o mito corrente do cerco fisiológico, esta seria uma prova do estado protocívico da população. Prefiro interpretá-la como expressão da mais sensata pauta de prioridades dos miseráveis, legitimamente transmitida àqueles com mandato para solucioná-las. A alternativa seria os desassistidos resolverem seus problemas por conta própria - o que aliás, também fazem, entretanto, por etapas.

A tabela 3 informa qual porcentagem, dentro de cada classe de 
renda, procurou políticos ou governantes para dar sugestóes, antes que pedir ou reivindicar algo.

\section{Tabela 3}

Porcentagem de contato com políticos para dar sugestóes, sobre total de contatos por classe de renda

(Pessoas de 18 anos ou mais)

\begin{tabular}{lrrrrr}
\hline Classe de renda & N & NE & SE & S & CO \\
\hline Até $1 / 2$ & 3,8 & 2,2 & 3,7 & 5,7 & 2,1 \\
$>1 / 2$ até 1 & 7,4 & 3,6 & 7,7 & 7,3 & 5,3 \\
$>$ 1 a 2 & 12,0 & 6,0 & 7,0 & 6,5 & 7,7 \\
$>$ 2 a 3 & 13,1 & 14,5 & 10,2 & 11,0 & 11,0 \\
> 3 a 5 & 14,5 & 14,3 & 12,3 & 15,5 & 8,0 \\
$>$ 5 a 10 & 8,2 & 13,0 & 8,5 & 17,0 & 16,2 \\
+ 10 & 17,0 & 21,0 & 14,4 & 16,1 & 20,6 \\
Sem rendimento & 34,6 & 25,0 & 28,0 & 29,5 & 23,4 \\
\hline
\end{tabular}

Fonte: FIBGE. Participaçäo politico-social, v.2, citado, várias tabelas.

Gritante e sistemático em todas as regióes do país, quanto maior a renda, maior o número de pessoas nessa faixa de renda disposta a contribuir com propostas para a melhoria do desempenho da classe política. Agora, o outro lado da moeda, conforme a tabela 4:

As evidências estão aqui dispostas de outra maneira. Trata-se de esclarecer a origem, por classe de renda, das pessoas que estabeleceram contatos políticos com o objetivo de formular pedidos. As informações são cristalinas. Na região Norte, dos contatos para pedidos, $61 \%$ foram feitos por pessoas sem rendimento ou que obtinham até um piso nacional de salário por mês. No Nordeste, $60 \%$ dos contatos para pedidos também foram feitos pelo contingente humano compreendido pelas classes sem rendimento e um piso nacional de salário. No Sudeste, $51 \%$ dos pedidos emanaram do leque sem rendimentos até entre um e dois PNS. No Sul, $50 \%$ dos pedidos vieram, ainda, dos sem rendimento e daqueles que auferiam até trés pisos nacionais de salários. Finalmente, no CentroOeste, $\mathbf{5 1 \%}$ dos pedidos foram formulados por pessoas entre sem rendimento até dois pisos nacionais de salairios.

Naturalmente, quem menos tem, mais pede. $O$ que desafia interpretaçóes - descartando-se, por improvável, a tese do cerco fisiológico - é justamente a inexistência de tal cerco. $O$ número total de 


\section{Tabela 4}

Pessoas de 18 anos e mais que tiveram contato com políticos para formular pedido, por regiáo e classe de renda - 1988

\begin{tabular}{|c|c|c|c|c|}
\hline Regiāo & Renda/\% & Renda/\% & Renda/\% & Total/\% \\
\hline \multirow[t]{2}{*}{ Norte } & Sem renda & $>1$ a 2 & $>1 / 2$ a l & \\
\hline & 24,0 & 20,0 & 17,0 & \\
\hline \multirow[t]{2}{*}{ Nordeste } & Sem Renda & $>1 / 2$ a 1 & Até $1 / 2$ & \\
\hline & 24,0 & 22,0 & 20,0 & \\
\hline \multirow[t]{2}{*}{ Sudeste } & Sem Renda & $>1$ a 2 & $>1 / 2$ a 1 & \\
\hline & 20,0 & 18,0 & 13,0 & \\
\hline \multirow[t]{2}{*}{ Sul } & $>1$ a 2 & Sem Renda & $>2 \mathrm{a} 3$ & \\
\hline & 21,0 & 15,0 & 14,5 & 00,0 \\
\hline \multirow[t]{2}{*}{ Centro-Oeste } & $>1$ a 2 & Sem Renda & $>1 / 2$ a 1 & \\
\hline & 22,0 & 17,0 & 12,0 & $4 \%, 0$ \\
\hline
\end{tabular}

Fonte: FIBGE. Participafáo poltitico-social, v.2, citado, várias tabelas.

contatos na região Norte, qualquer tipo de contato, não correspondeu a mais de $5 \%$ dos contatos possíveis; no Nordeste o volume de contatos náo passou de $7 \%$, ficou em 5,3\% no Sudeste, atingindo 9,3\% e 8,6\% no Sul e Centro Oeste, respectivamente. Ou seja, em todo o país o número de contatos de todo tipo, náo somente para pedidos, entre os cidadãos e políticos não alcançou sequer $10 \%$ dos contatos possíveis possíveis e esperados - que acontecem em uma democracia. A margem do Estado, por antipatia mútua e sobrevivendo na periferia da classe política com a qual mantém relaçóes cerimoniosas, de que forma a população brasileira administra suas carências e conflitos, isto é, quando reconhece que os tem?

Existe no Brasil um estado da natureza em sentido hobbesiano, ou seja, aquele no qual o conflito é generalizado e a regra constitucional vigente é cada qual administrar seus próprios problemas, sem apelo a instâncias superiores, aceitas pelas partes beligerantes. Ei-lo: $43 \%$ das pessoas que entre 1985 e 1988 admitiram envolvimento de algum tipo de conflito e náo recorreram à justiça, resolveram-no por conta própria. 


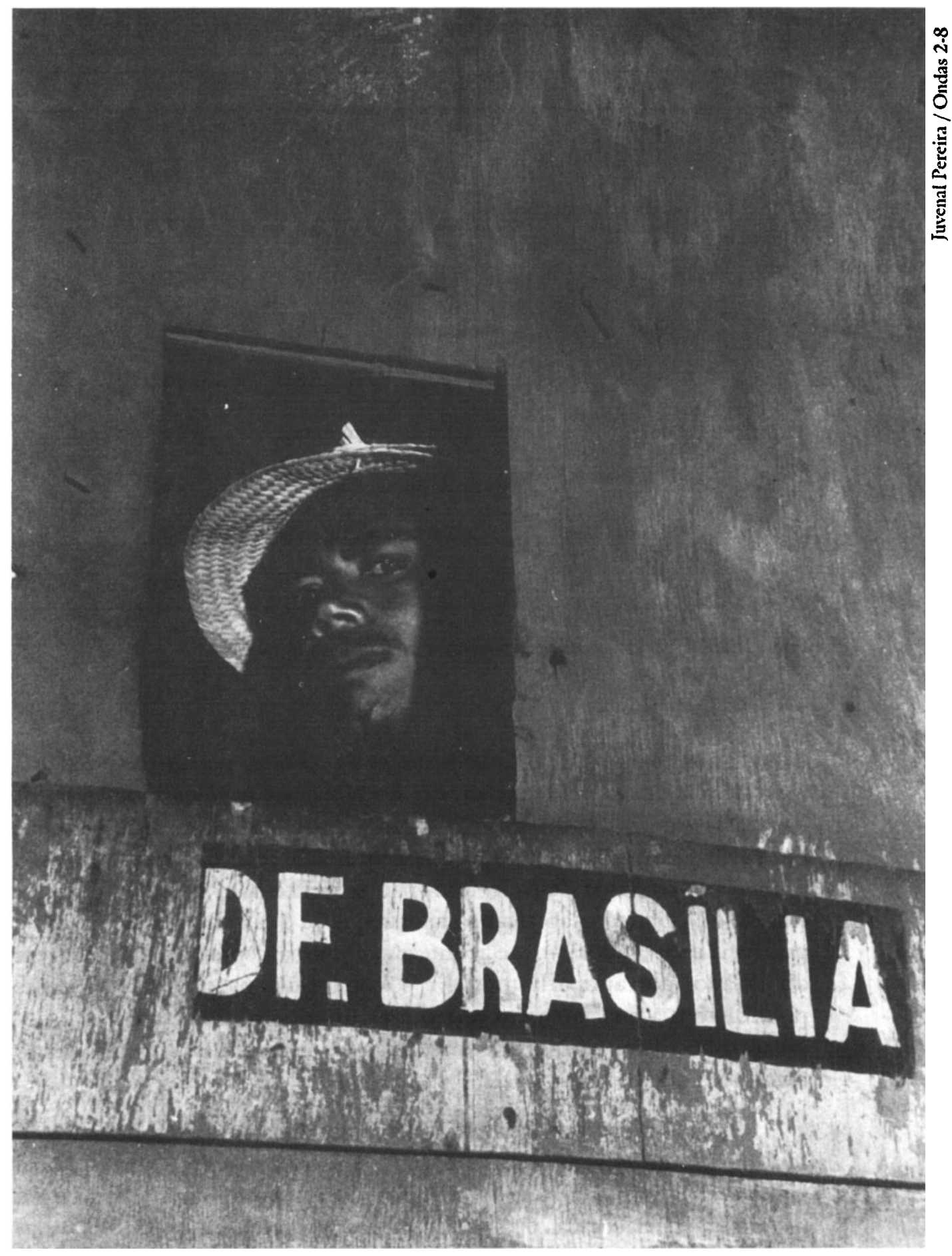

Operário da construgáo civil em caminbăo de transporte 
Isso no Brasil como um todo. Por regiáo, as porcentagem foram: Norte, 41\%; Nordeste, 34,2\%; Sudeste, 42\%; Sul, 50\%; e Centro- Oeste, $\mathbf{5 5 \%}$. Considerável parcela da população brasileira concentra em si mesma os poderes legislativo, executivo e judiciário, em contrapartida à desconsideração pela classe política (falsidade da hipótese do cerco fisiológico) e recusa em recorrer aos órgáos de segurança (executivo) e à justiça. Sabendo-se, ademais, que pouquíssimos se valem de outras pessoas ou entidades alternativas (6\% para o Brasil, de um total de 8.641.761 pessoas, admitiram envolvimento em conflitos, conforme tabela 1), torna-se sedutora a hipótese de que a violência difusa, aleatória, que parece caracterizar a sociedade brasileira contemporânea, encontra a sua principal origem no descrédito das instituiçóes políticas e estatais. Entretanto, para que então servem os sindicatos, dado sua função histórica ter sido a de domesticadores de conflito, canalizando-os para o leito institucional da competição política? De que modo é possível possuirmos, conforme outro mito institucional, sindicatos politizados, politizante $\mathrm{e}$, ao mesmo tempo, extensa e profunda deseducação cívico-institucional?

Não obstante as críticas conservadoras de que os sindicatos no Brasil sáo ao mesmo tempo não-representativos e politiqueiros - e talvez até não-representativos porque ilegitimamente politiqueiros - , isto não passa de outro componente da mitologia institucional brasileira. Em primeiro lugar, o número de pessoas ocupadas e filiadas a sindicatos ou associaçóes de empregados é incomparavelmente superior ao número de pessoas filiadas a partidos políticos. As porcentagens de pessoas maiores de dezoito anos filiadas a partidos por regiāo, em 1988, era: Norte, 3\%; Nordeste, 3\%; Sudeste, 2\%; Sul, 2,4\%; e Centro-Oeste, $5,7 \%$. Abaixo, a tabela 5 , referente à filiação sindical:

\section{Tabela 5}

Filiação a sindicatos ou associações do total de pessoas ocupadas, por regiấo, em 1988

\begin{tabular}{rrrrrc}
\hline Brasil & Norte & Nordeste & Sudeste & Sul & Centro-Oeste \\
\hline $18 \%$ & $15 \%$ & $15 \%$ & $17 \%$ & $23 \%$ & $17 \%$ \\
\hline
\end{tabular}

Fonte: FIBGE, Participafáo politico-social, v.2, citado, várias tabelas

Contrariamente ao que conservadores pensam e bem pensantes temem, a estrutura sindical brasileira é, de fato, representativa. Os níveis de filiaçáo são razoáveis e jogam com números absolutos de grande 
magnitude. Por que, então, não conseguem os sindicatos constituíremse em equivalente funcional às instituiçōes do Estado e converterem-se em mediadores, em processadores dos conflitos nos quais parte de sua clientela se vê envolvida e prefere resolver por conta própria? Justamente porque a populaçáo não considera os sindicatos instância legítima de resolução de qualquer conflito, ou como vocalizador político de alguns desses conflitos, mas como alternativa ao Estado para a prestação de dois serviços bastante precisos: assistência médica e assistência jurídica.

A irrelevância da estrutura sindical como espécie de sistema de pedagogia política, pelo menos da magnitude que se imagina, é atestada por alguns resultados de inquéritos recentes. Do total de pessoas ocupadas no setor primário da economia, filiadas a sindicatos, $83,6 \%$ utilizam-se de seus serviços médicos ou de assistência jurídica, somente $3,8 \%$ participando de suas atividades políticas. Os números relativos ao setor secundário são, respectivamente, $61,4 \%$ e 14,1\% e, ao terciário, $52,3 \%$ e $13,4 \%$ (Participacaio, v.2, p.10, tabela 4.5). Totalizando os setores, obtém-se: utilizaçáo de assistência médico-jurídica, 62,1\%; atividades políticas, $12 \%$.

Esse padräo de uso dos sindicatos reflete com fidelidade o motipo pelo qual as pessoas se associaram: $73 \% \mathrm{em}$ busca de assistência médico-jurídica e 14,4\% atraídos pela participaçáo política (Participafáio, v.2, p.14, tabela 4.7). Os sindicatos brasileiros parecem apresentar-se como razoavelmente representativos e sem apelo como agências de socialização política e de administração de conflitos, ao contrário do que sustenta o mito. Esse relativo fracasso do sindicato como agenciador de conflitos, por outro lado, somar-se-ía à deterioraçáo das instituiçóes estatais, propiciando oportunidades para a emergência do hobbesianismo social, do qual se falou, caracterizado pela concentraçáo nos indivíduos dos poderes legislativo, executivo e judiciário, levando-os a preferir resolver de forma privada e por conta própria seus conflitos, resultando, finalmente, na imagem de uma sociedade difusa e aleatoriamente violenta.

Violenta, sim, mas suspeito que a aleatoriedade que se atribui à violência, particularmente urbana, equivalha a outro mito do tesouro das lendas nacionais. Náo pode ser considerado errático o exercício da violência quando $59 \%$ das agressóes físicas cometidas no ano de 1988 tiveram por autores pessoas conhecidas (40\%) ou parentes (19\%), enquanto agressóes na rua, por desconhecidos, alcançavam 35,5\% (Participafcio, v.1, p.9, tabela 2.7). No capítulo de agressáo a mulheres, $32 \%$ delas foram vítimas de seus próprios parentes e outras $34 \%$ atingidas 
por pessoas conhecidas. Ou seja, $66 \%$ de agressores a mulheres, no Brasil, encontram-se em círculos familiares ou de amizades. Essa violência nada tem de errática sendo, ao contrário, bem localizada. Sabendo-se disso, como as vitimas sabem, existe alguma hipótese para que se imagine o porquê de sua reiteração e expansáo?

Creio que sim. Fundamentalmente, a impunidade estimula a repetição da violência e, ao mesmo tempo, faz com que decresça no agressor a expectativa de algo lhe acontecer. Assim, a ausência de punição, ao contrário de oferecer oportunidade, ou segunda chance para que o autor reveja o seu comportamento, constitui ingrediente para a redução nas probabilidades de puniçáo, cálculo do agressor e, senão estímulo, pelo menos redução nas barreiras à repetição da violência.

Notoriamente, e dados já foram aqui expostos, grande parte da populaçáo descrê da polícia e do judiciário. Com efeito, a eficiência de ambos deixa a desejar, dizendo o mínimo. Dois outros mecanismos sociais, porém, alimentam também a impunidade e, por conseqüência, contribuem para o cálculo perverso segundo o qual a repetição da violência reduz a probabilidade de puniçáo. Considere-se, como evidência, que de todas as pessoas vítimas de agressão em 1988, $61 \%$ náo deram queixa à polícia. Em outras palavras, as vítimas inocentam preliminarmente os agressores, sem processo, acusaçăo ou julgamento. Pior ainda: $60 \%$ das pessoas agredidas por parentes náo registraram queixa e $62 \%$ das vítimas de conhecidos também silenciaram.

Obviamente, a repetição da violência será probabilisticamente maior quando o agressor, impune, continua a conviver com sua vítima, do que quando o agressor foi um aleatório desconhecido ao passar na rua. Deixar de registrar queixa com relação a este último é incorreto, mas não aumenta significativamente a possibilidade de que alguém venha a ser vítima do mesmo agressor por razóes de impunidade. Neste caso, a violência pode ser interpretada como aleatória, errática. No caso de familiares e parentes, não. A impunidade é grave e sério estímulo à reincidência e, por isso, as estatísticas revelam parentes e conhecidos como contumazes agressores. Essa violência náo é errática.

Năo é diferente o padrão agressão-impunidade-reincidência, de onde se segue violência localizada e sabida, no que concerne a mulheres vitimadas. Do total de mulheres vítimas de agressão em $1988,58 \%$ não deram queixa, aí incluídas $\mathbf{5 8 , 5 \%}$ das que foram vítimas de parentes e não declararam e, também, $53,7 \%$ do total de vitimadas por pessoas conhecidas, que permaneceram caladas (estatísticas retiradas de dados citados em Participação, v.1, várias tabelas). Esta violência também não é errática. 
Encontra-se aqui complexo e ardiloso mecanismo que ajuda a compreender a expansão da violência não-aleatória, não-errática. Relaçōes de parentesco e amizade, por criarem laços de solidariedade social, resistem por mais tempo e com maior tolerância a transgressóes, assim como ofensas aos códigos que fundamentam as próprias relaçóes. Expor um transgressor desses códigos a alguma puniçáo implica imediata e eventualmente intensa ameaça de ruptura daqueles laços e, em consequiência, a substituição da solidariedade microcomunitária pelo conflito hobbesiano. Daí, talvez, a disposição de absorver o ônus de sofrer uma agressão, sem denúncia, na suposiçáo de que este seja menor do que o custo da ruptura da solidariedade, em caso de haver denúncia. O dilema, portanto, com relaçáo a parentes e conhecidos, parece claro: sofrer em silêncio a agressão e manter a solidariedade comunitária, ou denunciá-la e substituir a comunidade pelo conflito - pela solidão, no mínimo. Como visto, a maioria esmagadora dos ofendidos, incluindo as mulheres, apostam na estratégia do silêncio.

O lastimável, porém, é que o cálculo perverso do agressor toma o silêncio e a impunidade não como reafirmação e convite para que sejam mantidos intactos os laços de solidariedade; ao contrário, o silêncio e a impunidade são tomados como licenfa excepcional para a violação das regras de integração social. O padrão implícito no silêncio é interpretado como crédito, como reconhecimento de uma dívida a que tinha direito perante um ou mais membros do grupo. Assumindo ao mesmo tempo os papéis de legislador, executor e juiz, e tendo, conforme interpreta, sido reconhecido como tal, qual meta-regra de integraçáo comunitária poderá impedi-lo de, outra vez, exercer o poder que lhe foi outorgado?

A repetiçáo das ofensas e transgressóes termina por provocar, via impunidade, precisamente o que a impunidade deseja evitar - a destruiçáo dos laços de solidariedade comunitária e a instalação, em nível micro, do hobbesianismo social e da tirania dos mais violentos. $O$ que o silêncio produz não é mais a esperança de conservaçáo comunitária, mas o medo, o medo terrível de novas humilhaçóes, novas ofensas, novas agressóes, e estas, agora sim, absolutamente aleatórias e erráticas. Mas o medo não se distribui igualmente em uma sociedade desigual. Quem tem medo, quem treme de medo, quem morre de medo no Brasil?

Se existem os que não confiam à polícia ou à justiça os agravos ou injúrias que padeceram por descrença - temporária ou definitiva - $\mathrm{e}$ se existem os que não o fazem por conta de transtornado individualismo, tentando resolver eles próprios o que a eles não compete e, ainda, se multiplicam-se os que buscam ajuda de terceiros, vingadores quiçá, 
para a remissão de males já cometidos, existem também aquelcs que não tornam publicamente registrados os agravos dos quais foram vítimas por uma desesperada razáo: o medo. O medo à represália, o medo de que o apelo à segurança a eles devida exacerbe ao limite o estado de insegurança em que já vivem. Medo cotidiano, fragilizante, retaguarda segura de criminosos e tiranetes. Medo que se dissemina pela superfície, mas não pela pirâmide social do país. Aos fenômenos como de fato são: quem tem fome, tem medo.

Para que não se percam em estatísticas oficiais, aqui registram-se algumas evidências desse medo aterrador, a dar razão a Hobbes e a Maquiavel com o atraso de alguns séculos. Dois pisos nacionais de salários nada são, e pouco mais sáo cinco pisos nacionais de salários, mas a distância entre dois e cinco cobre o hiato entre o terror e o relativo sossego; ao entrar em contato com forças policiais, por hipótese. Fatos: do total de vítimas por agressão física que evitaram dar queixa à polícia, em 1988, 41\% ganhavam até dois pisos nacionais de salários. Os que ganhavam mais de cinco pisos não constituíam mais do que $8 \%$ dessa multidáo de cúmplices silenciosos. Da totalidade de pobres, silenciosos e cúmplices (até dois pisos nacionais), 19,4\% não queriam envolver a polícia, $11,6 \%$ nela não acreditavam e $11 \%$ temiam represálias diretas; ou seja, $42 \%$ do total de vítimas pobres calaram-se por conta de alguma forma de terror. Dos afluentes beneficiados com mais de cinco pisos mensais, e também vítimas de agressáo física que silenciaram, $15,6 \%$ não queriam envolver a polícia e somente $3,8 \%$ temiam represálias. $O$ medo, no Brasil, é a compensaçáo em tributo social da isenção de imposto sobre a renda.

Mas o retrato da distribuiçáo social do medo requer ainda alguns retoques de precisão. Importa considerar, sobretudo, além da contribuição dos cúmplices silentes para o contingente total de silenciosos, por classe de renda, a composição interna, por renda, dos que se calam por pavor. No Brasil, em todas as regióes, o retrato aperfeiçoado será praticamente o mesmo. Escondem-se, calam-se, nada comunicam à polícia das agressóes sofridas, em primeiro e esmagador lugar, aqueles brasileiros que não dispóem de rendimento regular para declaração. No país, como um todo, eles correspondem a $37 \%$ dos humilhados, ofendidos e amedrontados - por isso silentes. A estatística atinge $40 \%$ no Nordeste, $39 \%$ no Sudeste e $39 \%$ no Sul. Os sem rendimentos correspondem a $20 \%$ no Centro-Oeste e a $6 \%$ no Norte, com todas as deficiências estatísticas, e conhecidas, da regiáo. De qualquer modo, a vasta maioria dos amedrontados é constituída pelos que não detêm praticamente qualquer poder de mercado. 
Se excluirmos agora do total de amedrontados a parcela dos que não recebem renda regular, as estatísticas tornar-se-ão verdadeiramente impressionantes. Do total de ofendidos e amedrontados, que não obstante auferem alguma renda, $71 \%$ estão classificados em até dois pisos nacionais de salários. Na regiáo Norte, o contingente de amedrontados que auferiam até dois pisos nacionais de salários davam conta de $71 \%$ do total dos que não reportaram agressão física por temor a represálias. No Nordeste, a mesma categoria alcança $90,4 \%$ (amedrontados e com renda até dois pisos nacionais), no Sudeste $64 \%$, no Sul $67,4 \%$ e no Centro-Oeste $\mathbf{8 4 \%}$ (fonte dos dados para toda esta reflexão sobre a distribuiçáo do medo em Participação, v.l, várias tabelas).

Este medo que, juntamente com a fome, consome grande parte da população brasileira, consome também a justiça e a ordem. De um lado, a expectativa de manter laços de solidariedade comunitária $\mathrm{em}$ níveis razoáveis de custos de transgressão; e, de outro, a aterrorizante expectativa de conseguir, pelo silêncio, reduzir a zero os custos de transação, associam-se para gerar, pela via da impunidade, o oposto do que almejavam - em lugar de previsibilidade quanto ao dia seguinte da vigência de regras já profundamente assimétricas, o sobressalto permanente, $o$ arbítrio, a desordem sem fim. É ilusório supor, e irresponsável sugerir, que quem manda nessas regiōes aparece em televisão. Quem nelas impera é o crime organizado, a violência localizada e nada aleatória, os fabricantes do desemprego e, em conseqüência, da opressão e do medo, as instituições que vivem do povo, mas não sabem como, ou não o querem, educá-lo. Quem manda nessas regiôes não são, quem dera até que o fossem, as mitologias institucionais correntes. Quem nelas manda é o catálogo heraclíteo da noite.

Wanderley Guilherme dos Santos é profcssor do Instituto de Filosofia e Ciências Sociais da Universidade Federal do Rio de Janeiro.

Este trabalho foi apresentado no seminário "Autoritarismo social versus democratização do Estado: desafios à educação", realizado no Instituto de Estudos Avançados (IEA) da USP, de 15 a 17 de fevereiro de 1993, patrocinado pelas seguintes instituiçóes: Unesco Institute for Education (UIE) - Hamburgo, OREALC; Instituto de Estudos da Religião (ISER); Instituto Nacional de Estudos e Pesquisas Educacionais (INEP); Instituto de Estudos Avançados (IEA) da USP The Ford Foundation; Fundação Carlos Chagas; Fórum Permanete da FGV e CLACSO. O evento foi organizado pelos professores-doutores Sérgio Costa Ribeiro e Vanilda Paiva. 